Chirurgia (2020) 115: 747-755

No. 6, November - December Copyright@ Celsius

http://dx.doi.org/10.21614/chirurgia.115.6.747

\title{
An Overview of Five-Year Survival in Rectal Cancer in Relation to Lymph Node Status
}

\author{
Zalán Benedek', Szabolcs Todor Boér ${ }^{2 *}$, Orsolya Bauer', Kálmán Sárdi ${ }^{3}$, Attila Todor ${ }^{4}$, Nicolae Suciu', \\ Marius Florin Coros ${ }^{1}$
}

'Surgical Clinic, Mureș County Emergency Hospital, "G.E. Palade” University of Medicine, Pharmacy, Science and Technology, Târgu Mureș, Romania

${ }^{2}$ Surgery Clinic, Mureș County Clinical Hospital, Târgu Mureș, Romania

${ }^{3}$ 2nd Surgery Clinic, Mureș County Emergency Hospital, Târgu Mureș, Romania

4"G.E. Palade" University of Medicine, Pharmacy, Science and Technology, Târgu Mureș, Romania

*Corresponding author:

Todor Boér Szabolcs, MD

Surgery Clinic

Mureș County Emergency Hospital 22 Decembrie 1989 street, no 6/20 Postal Code: 540109, Târgu Mureș E-mail: tbszabi@yahoo.com
Received: 03.10.2020 Accepted: 06.12.2020

\section{Rezumat}

Studiul supraviețiirii pe cinci ani în cancerul rectal în raport cu starea ganglionilor limfatici

Introducere:Metastazele ganglionare sunt considerate un factor de prognostic important în supraviețuire şi recidiva bolii la pacienții cu cancer colorectal. Mai multe studii arată faptul că raportul ganglionilor limfatici are o importanță mai mare în supraviețuire decât numărul ganglionilor limfatici metastatici. Scopul acestui studiu este de a analiza supravietuirea la 5 ani a pacientilor cu cancer rectal, examinând mai mulți factori de prognostic, cu accent pe starea ganglionilor limfatici.

Material şi metode: Studiul retrospectiv a fost efectuat la o clinică de chirurgie din România, utilizând date de la pacienții care au fost tratați pentru cancer rectal în perioada ianuarie 2009 - decembrie 2014. Starea actuală a pacientului şi în ceea ce priveşte tratamentul multimodal a fost evaluată prin metodă telefonică, datele au fost extrase din baza de date a clinicii şi din buletinele histopatologice.

Rezultate: În studiul actual au fost incluşi 144 de pacienți cu cancer rectal. Analiza statistică a variabilelor a arătat că vârsta ( $p=0,001)$, Stadiul T ( $p=0,049)$, stadiul N ( $p=0,005)$, LNR ( $p=0,006)$, tipul de intervenție chirurgicală $(\mathrm{p}<0,001)$, prezența invaziei vasculare $(p<0,001)$ şi prezența metastazelor $(p<0,001)$ sunt factori prognostici semnificativi pentru supraviețuire în analiza univariată. Concluzii: Supraviețuirea la 5 ani a pacienților incluşi în studiu a 
fost $63,9 \%$. Prin concluzie s-a dovedit că starea ganglionilor limfatici, exprimată prin raportul ganglionilor limfatic (LNR) este un factor prognostic semnificativ în supraviețuire.

Cuvinte cheie: cancer rectal, factori de prognostic, supraviețuire, starea ganglionilor limfatici

\begin{abstract}
Introduction: Lymph node metastasis is regarded as an important prognostic factor for predicting disease recurrence and survival in patients with colorectal cancer. Several studies suggest that the lymph node ratio has a greater importance in survival than the number of metastatic lymph nodes. The scope of this study is to examine the 5-year survival of rectal cancer patients, examining several prognostic factors with emphasis on lymph node status.

Material and methods: A retrospective study was conducted at single surgical clinic from Romania, using data from patients who have been treated for rectal cancer between January 2009 and December 2014. Patient present status and regarding the multimodal treatment was assessed through telephonic method, data was extracted from the electronic database of the clinic and histopathological reports.

Results:A total number of 144 patients affected by rectal cancer were assessed. Statistical analysis of the variables showed that age $(p=0.001)$, T stage $(p=0.049), N$ stage $(p=0.005), L N R(p=0.006)$, type of surgery $(p<0.001)$, presence of vascular invasion $(p<0.001)$, metastases $(p<0.001)$, to be significant prognostic factors for survival.

Conclusions: The 5-year survival of the patients we included in the study was $63,9 \%$. Nodal status, expressed by lymph node ratio proved to be a significant prognostic factor of patient survival.
\end{abstract}

Key words: rectal cancer, prognostic factors, survival, lymph node status

\section{Introduction}

Colorectal cancer is one of the most common malignant causes of death, according to GLOBOCAN data is the third most deadly and the fourth most commonly diagnosed malignant disease and it is becoming increasingly more frequent. Also known as colorectal adenocarcinoma, the common origin is a formation of a benign polyp by hyperproliferative cells, which becomes malignant over time, after being exposed to irritating factors and also could metastasize (1).

Colorectal cancer is evaluated in most cases as a single entity regarding the prognostic factors and survival rate. There are some similar aspects in the treatment strategy but we should have to evaluate separately to avoid ignoring useful information that will be beneficial to the study. The survival rate is defined as the proportion of patients who have been diagnosed with cancer and survived at an established period after diagnosing the malignant disease. The difference in survival rates varies due to some factors: age, sex, economic status, genetic, histology type, tumor size, stage, comorbidities, etc. In developed countries the 5-year survival rate is higher than $60 \%$ in colorectal cancer, according to the American Cancer Society, the overall 5-year survival rate of rectal cancer patients is $67 \%$ $(2,3)$.

There are many risk factors associated with increased cancer incidence. The main method of treatment is surgical excision/resection of the tumor accompanied in most of the cases by radiotherapy and/or chemotherapy which can be pre or postoperative. Treatment options vary depending on tumor localization, characteristic, and stage it is discovered at $(4,5)$. 
Improvements in colorectal cancer treatment led to a decrease in mortality in the second and third categories of nations, even if the incidence is increased. The result of greater survival is due to the evolution of the diagnostic and treatment methods such as flexible sigmoidoscopies, colonoscopies, endoscopic removal of polyps, computed tomography, MRI, fecal occult blood testing, etc.

Prognostic factors examined in multiple studies include nodal status, including excised lymph node number, lymph node ratio, TNM stage, distant metastases, vascular invasion, age at diagnosis, gender, tumor localization, tumor differentiation (6).

This study aimed to examine the 5-year survival of rectal cancer patients from a single-center, examining several prognostic factors with emphasis on lymph node status.

Our working hypothesis which we have set out to prove is that different variables such as lymph node ratio, positive lymph nodes, $\mathrm{T}$ and $\mathrm{N}$ stage, the presence of distant metastases, age, sex, type of surgery, tumor differentiation, localization, tumor aspect, vascular invasion prognostic factors which influence survival rates in rectal cancer.

\section{Materials and Methods}

A retrospective cohort study was conducted at the Surgery Clinic of Mureş County Clinical Hospital, using data from patients who have been treated for rectal cancer between January 2009 and December 2014. Three hundred and forty patients (340) were operated for rectal cancer between January 2009 and December 2014 in the Surgical Clinic of Mures County Clinical Hospital.

The data of rectal cancer patients were obtained from the electronic database, clinical files, and histopathological reports. The examined data included: patient's age, sex, tumor differentiation, lymph nodes excised, number of positive lymph nodes, presence of metastases, tumor localization, aspect, type of operation, vascular invasion.

The status of each patient was assessed by telephonic method by a questionnaire regarding the patient's actual status, survival time, cause of death, information about the treatment strategy and controls, tumor recurrence. In this survival analysis, the follow-up time was starting from the surgery until the date of cancer-related death or the end of follow-up (December 2019). At the end of the telephonic assessment, we obtained complete data from 144 patients for the study. Patients with incomplete histopathological data and/or incomplete follow up information or simply refused to answer our query, were excluded from the study. Patients deceased during their stay in the hospital were also excluded from statistical analysis.

Data analysis was stratified by age $(<40$, 40-49, 50-59, 60-69, 70-79, >79); gender; tumor differentiation grade(well, moderate, poor and mucinous), surgery performed (TME (Dixon), Hartmann, Miles, other); excised lymph nodes, tumor localization (upper 1/3, middle $1 / 3$, lower $1 / 3$ ), presence of vascular invasion and distant metastases.

Tumor staging and nodal status classification was realized according to TNM staging by the American Joint Committee on Cancer (AJCC), wherein regards to nodal status N0 means no nodal metastases were detected, N1 metastasis in 1-3 lymph nodes $(\mathrm{N} 1 \mathrm{a}+\mathrm{N} 1 \mathrm{~b}+$ N1c), N2 metastases in more than 4 lymph nodes $(\mathrm{N} 2 \mathrm{a}+\mathrm{N} 2 \mathrm{~b})$. The ratio between the number of excised lymph nodes, and metastatic ones were calculated, obtaining the lymph node ratio (LNR) in each case, and divided into the following four groups: LNR0 if the ratio was $<1 \%$, LNR1 if $1-20 \%$, LNR2 if $21-50 \%$, and LNR3 if $>50 \%$.

The statistical data types as binary, categorical, ordinal, binomial and count were organized into Microsoft Office Excel tables. Statistical analysis was conducted using the IBM SPSS Statistics 23 software, with a statistical significance level of $p<0.05$. Statistical analysis of the variables were performed with Student T test and ANOVA, and also multivariate analysis Survival data were obtained from Kaplan Meier and Log-Rank test. All tests were two-tailed.

This study is part of the project "Studiul 
factorilor de risc si a complicatiilor în chirurgia cancerului colorectal' and was approved by the Ethics Committee for Scientific Research of the University of Medicine Pharmacy, Science and Technology of Târgu Mureş.

\section{Results}

In our study 144 rectal cancer patients were included, $92(63.9 \%)$ were male and $52(36.1 \%)$ were female. The mean age was 62.81 years. Regarding the patient distribution by age, about $2 / 3$ of the patients were over 60 years and by gender also about $2 / 3$ of the patients were male.

Regarding the tumor localization we created three groups, where in 57 cases the tumor was localized in the upper third of the rectum, in 64 cases in the middle third, and 23 cases in the lower third of the rectum.

The studied cases were divided into four groups based on differentiation, adenocarcinoma 3 types (4 cases poor, in 110 moderate and 18 cases well-differentiated), and mucinous (12 cases) tumors were found.

We observed a larger number, $70.1 \%$ of T3 staged cases, $2.1 \%$ of cases were staged T1, $19.4 \%$ of cases were staged $\mathrm{T} 2$, and $8.3 \% \mathrm{~T} 4$.

In $16 \%$ of the cases studied vascular invasion was observed.

Regarding surgical treatment, in 63 cases patients underwent low anterior resection with colorectal anastomosis (Dixon's procedure), in 47 cases abdominoperineal resection with end colostomy (Miles operation), in 27 cases Hartmann's operation, and in 7 cases other procedures.

A mean number of 6.92 lymph nodes were collected, with a mean number of 1.45 positive lymph nodes among cases where at least one positive lymph node was observed.

At the histological examination, 84 cases were staged N0, 34 were staged N1, 26 cases were staged N2. Distant metastases were found in 23 cases, all hepatic metastasis.

Studying the patient's BMI and based on WHO body mass index classification we grouped our patients, we found that 2 patients BMI were underweight $18.5 \mathrm{~kg} / \mathrm{m}^{2}$, so these patients were included in the underweight group; 62 patients were with normal weight, BMI between $18.5-24.9 \mathrm{~kg} / \mathrm{m}^{2}$, 47 patients were overweight BMI between $25-29.9 \mathrm{~kg} / \mathrm{m}^{2}$, and 33 were obese with BMI above $30 \mathrm{~kg} / \mathrm{m}^{2}$.

\section{Statistical Analysis}

Statistical analysis of the variables, shown in Table 1, resulted in age $(\mathrm{p}=0.001), \mathrm{N}$ stage $(p=0.005), T$ stage $(p=0.049)$ LNR $(p=0.006)$, type of surgery $(p<0.001)$, presence of vascular invasion $(p<0.001)$, of metastases $(p<0.001)$ to be significant prognostic factors for survivalin univariate analysis

Other variables such as gender $(p=0.982)$, number of excised lymph nodes $(\mathrm{p}=0.533)$, differentiation $(\mathrm{p}=0.041)$, tumor localization $(p=0.259)$ and BMI $(p=0.290)$ did not prove to be significant prognostic factor in our series of cases. By multivariate analysis the age $(p=0.035)$, vascular invasion $(p<0.001), L N R$ $(p=0.001), N$ stage $(p=0.004)$ and distant metastases $(p<0.001)$ proved to be significant as prognostic factor in five year survival.

The results of the analyses are presented in Table 1.

The 5-year survival of all the patients included in the study was $63.9 \%$.

Overall survival of patients proved to be significantly influenced by the lymph node ratio $(p=0.006)$, a lower lymph node ratio resulting in a better survival rate.

Patients with a $<1 \%$ lymph node ratio (LNR 1) had a 5 -year survival of $75.6 \%$, in the LNR 1-20\% group (LNR 2) $50 \%$, in the LNR $21-50 \%$ group (LNR 3) $54.2 \%$, and in the LNR $>50 \%$ group (LNR 4) the 5-year survival was $42.9 \%$. Log-Rank test: $\mathrm{p}=0.003$ (Fig. 1).

Overall survival is significantly influenced by $\mathrm{N}$ stage, patients with higher stage having lower survival rates. The 5-year survival based on $\mathrm{N}$ stage groups is as follows: N0 stage group had a $75 \%$ survival, at N1 stage $47.1 \%$, $\mathrm{N} 2$ stage had 50\% 5-year survival rate. LogRank test: $\mathrm{p}=0.002$ (Fig. 2).

Global survival rate was significantly influenced by age $(p=0.001)$, the higher age group having a lower overall survival rate. 
Table 1. Interpretation and centralization of data

\begin{tabular}{|c|c|c|c|c|}
\hline & Variable & Number & Mean survival (months) & $p$ \\
\hline$\overline{\text { Age }}$ & $\begin{array}{l}40 \text { years } \\
40-49 \text { years } \\
50-59 \text { years } \\
60-69 \text { years } \\
70-79 \text { years } \\
>79 \text { years }\end{array}$ & $\begin{array}{c}3 \\
12 \\
35 \\
53 \\
36 \\
5\end{array}$ & $\begin{array}{c}73.33 \\
53.92 \\
70.66 \\
62.26 \\
48.03 \\
30.2 \\
\end{array}$ & $\begin{array}{l}p=0.001 \\
\text { (ANOVA test) }\end{array}$ \\
\hline Gender & $\begin{array}{l}\text { Male } \\
\text { Female }\end{array}$ & $\begin{array}{l}92 \\
52\end{array}$ & $\begin{array}{l}59.21 \\
59.10\end{array}$ & $\begin{array}{l}\mathrm{p}=0.982 \\
\text { (Student T-test) }\end{array}$ \\
\hline T stage & $\begin{array}{l}\text { T1 } \\
\text { T2 } \\
\text { T3 } \\
\text { T4 }\end{array}$ & $\begin{array}{c}3 \\
28 \\
101 \\
12\end{array}$ & $\begin{array}{l}78.00 \\
63.61 \\
59.64 \\
40.08\end{array}$ & $\begin{array}{l}p=0.049 \\
\text { (ANOVA) }\end{array}$ \\
\hline N stage & $\begin{array}{l}\text { N0 } \\
\text { N1 } \\
\text { N2 }\end{array}$ & $\begin{array}{l}84 \\
34 \\
26 \\
\end{array}$ & $\begin{array}{l}65.45 \\
51.15 \\
49.35 \\
\end{array}$ & $\begin{array}{l}p=0.005 \\
\text { (ANOVA test) }\end{array}$ \\
\hline LNR & $\begin{array}{l}<1 \% \\
1-20 \% \\
21-50 \% \\
>50 \%\end{array}$ & $\begin{array}{l}82 \\
10 \\
24 \\
28\end{array}$ & $\begin{array}{c}66.0 \\
51.0 \\
52.88 \\
47.46\end{array}$ & $\begin{array}{l}p=0.006 \\
\text { (ANOVA test) }\end{array}$ \\
\hline Differentiation & $\begin{array}{l}\text { Well } \\
\text { Moderate } \\
\text { Poor } \\
\text { Mucinos }\end{array}$ & $\begin{array}{c}18 \\
110 \\
4 \\
12\end{array}$ & $\begin{array}{l}59.89 \\
57.14 \\
79.50 \\
69.92\end{array}$ & $\begin{array}{l}\mathrm{p}=0.210 \\
\text { (ANOVA test) }\end{array}$ \\
\hline Surgery & $\begin{array}{l}\text { TME(Dixon) } \\
\text { Hartmann } \\
\text { Miles } \\
\text { Other }\end{array}$ & $\begin{array}{c}63 \\
27 \\
47 \\
7\end{array}$ & $\begin{array}{l}65.17 \\
43.26 \\
64.06 \\
33.57\end{array}$ & $\begin{array}{l}p<0.001 \\
\text { (ANOVA test) }\end{array}$ \\
\hline Excised lymph nodes & $\begin{array}{l}\leq 12 \\
>12\end{array}$ & $\begin{array}{c}128 \\
16\end{array}$ & $\begin{array}{l}59.68 \\
55.06\end{array}$ & $\begin{array}{l}p=0.533 \\
\text { (Student T-test) }\end{array}$ \\
\hline Tumor localisation & $\begin{array}{l}\text { Upper } 1 / 3 \\
\text { Middle } 1 / 3 \\
\text { Lower } 1 / 3\end{array}$ & $\begin{array}{l}57 \\
64 \\
23 \\
\end{array}$ & $\begin{array}{l}54.89 \\
60.72 \\
65.43 \\
\end{array}$ & $\begin{array}{l}p=0.259 \\
\text { (ANOVA) }\end{array}$ \\
\hline Vascular invasion & $\begin{array}{l}\text { Absent } \\
\text { Present }\end{array}$ & $\begin{array}{c}121 \\
23\end{array}$ & $\begin{array}{l}62.89 \\
39.57\end{array}$ & $\begin{array}{l}\mathrm{p}<0.001 \\
\text { (Student T-test) }\end{array}$ \\
\hline Distant metastases & $\begin{array}{l}\text { Absent } \\
\text { Present }\end{array}$ & $\begin{array}{c}121 \\
23\end{array}$ & $\begin{array}{c}65.2 \\
27.43\end{array}$ & $\begin{array}{l}p<0.001 \\
\text { (Student T-test) }\end{array}$ \\
\hline$\overline{\mathrm{BMI}}$ & $\begin{array}{l}\text { Underweight } \\
\text { Normalweight } \\
\text { Overweight } \\
\text { Obese }\end{array}$ & $\begin{array}{c}2 \\
62 \\
47 \\
33\end{array}$ & $\begin{array}{c}39.5 \\
55.08 \\
62.28 \\
63.61\end{array}$ & $\begin{array}{l}p=0.290 \\
\text { (ANOVA test) }\end{array}$ \\
\hline
\end{tabular}

The 5 year survival in case of patients $<40$ years (age group 1) was 66.7\%, 40-49 years age group 2) $58.3 \%$, 50-59 years (age group 3 ) $74.3 \%, 60-69$ years (age group 4) 73.6\%, 70-79 years (age group 5) $47.2 \%$ and $>79$ years (age group 6) $20 \%$.

The 5-year survival in patients by age group is presented in Fig. 3. Log-Rank test: $\mathrm{p}=0.01$

Global survival based on tumor differentia- tion level doesn't show a statistically significant difference between groups $(\mathrm{p}=0.21)$, patients with well-differentiated tumors (group 1) had a higher survival rate than those with moderately differentiated (group 2) ones. The patient group with poorly differentiated (group 3) and mucinous adenocarcinoma tumors (group 4) had higher overall survival, but the group consisted of only 4 and 12 cases. The 5-year survival of the well-differentiated group was 


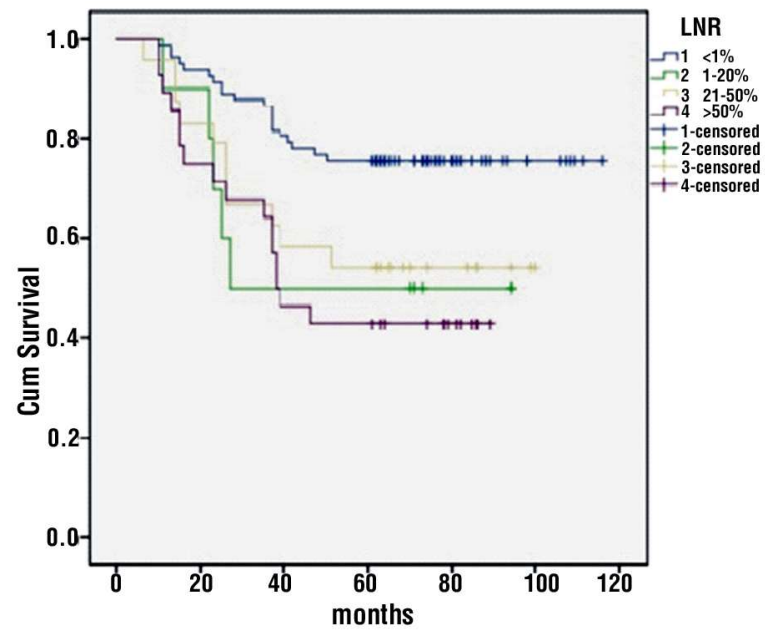

Figure 1. Overall survival based on lymph node ratio

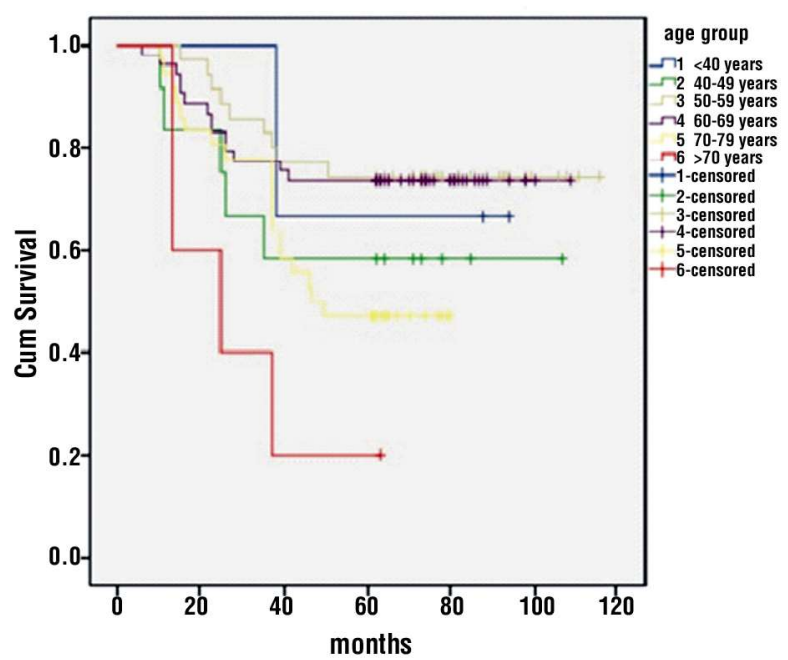

Figure 3. Overall survival based on age groups

$72 \%$, in the moderate group $60.9 \%$, the poorly differentiated group had a $100 \%$ and the mucinous group 66.66\% 5-year survival rate.

The global survival rate was significantly influenced by the performed surgical procedure $(\mathrm{p}=0.004)$.

Patients undergoing low anterior resection with colorectal anastomosis (Dixon's technique) and abdominoperineal resection (Miles operation), had a higher 5-year survival rate, $74.6 \%$, and $68.1 \%$. Patients undergoing Hartmann's procedure had a 5-year survival rate of $40.7 \%$, the other group had a survival

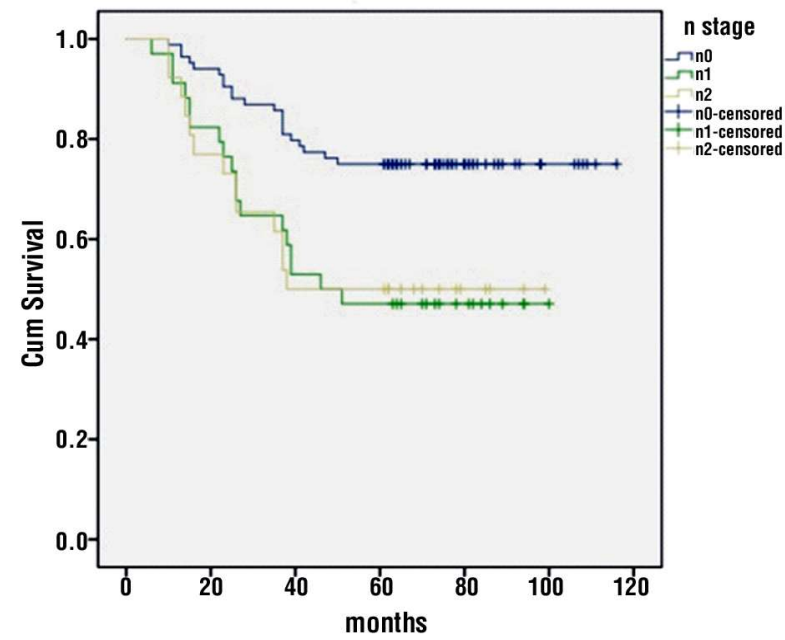

Figure 2. Overall survival based on $\mathrm{N}$ stage

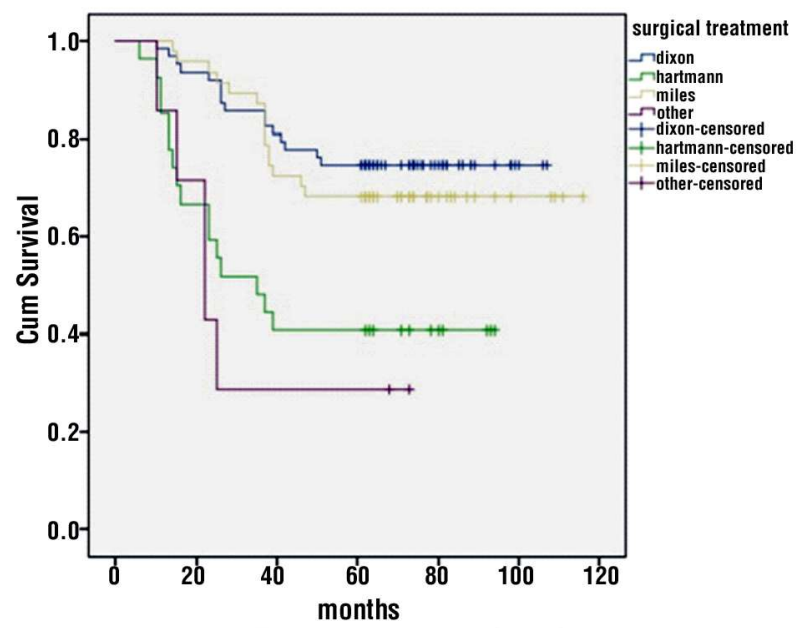

Figure 4. Overall survival based on surgical procedures

rate of $28.57 \%$. Log Rank test: $\mathrm{p}<0.001$ (Fig. 4 ).

The presence of vascular invasion had a significant influence on global survival $(p<0.001)$, those with observed vascular invasion had a lower survival rate.

In the group where no vascular invasion was detected the 5-year survival was $70.24 \%$, where the vascular invasion was present the survival rate dropped to $30.43 \%$.

The presence of distant metastases showed a significant influence on overall survival $(p<0.001)$, where those with detected distant metastases had a lower survival rate than the 
group with none. 5-year survival is $71.9 \%$ in patients with no distant metastases, while in the case of metastases this value is $21.7 \%$.

Our results show that the difference in overall survival was not statistically significant, but a higher survival rate in patients with higher BMI was observed. A 5 year survival rate in case of underweight patients was $0 \%$ (group 1), normal weight patient (group 2) 61.3\%, overweight patient (group 3) $68.1 \%$, obese patients (group 4) $66.7 \%$.

In our study gender did not have a significant effect on patient survival $(p=0.983)$. 5year survival in case of males was $64.1 \%$ and in case of females $63.5 \%$.

The $\mathrm{T}$ stage proved to be a significant prognostic factor in the series of patients we included in the study $(p=0.049)$. 5-year survival in cases staged T1 was $100 \%$, in cases stage T2 67.9\%, in T3 stage $64.4 \%$, and in stage T4 in was $41.7 \%$. Log Rank test: $\mathrm{p}=0.047$ (Fig. 5).

Overall survival was not significantly influenced by the number of excised lymph nodes $(\mathrm{p}=0.593)$. Regarding 5 -year survival the group with equal or less than 12 lymph nodes collected had a $65.6 \%$ survival rate, while the group with more than 12 lymph nodes collected had a 5-year survival rate of $50 \%$.

Tumor localization did not have a signifi-

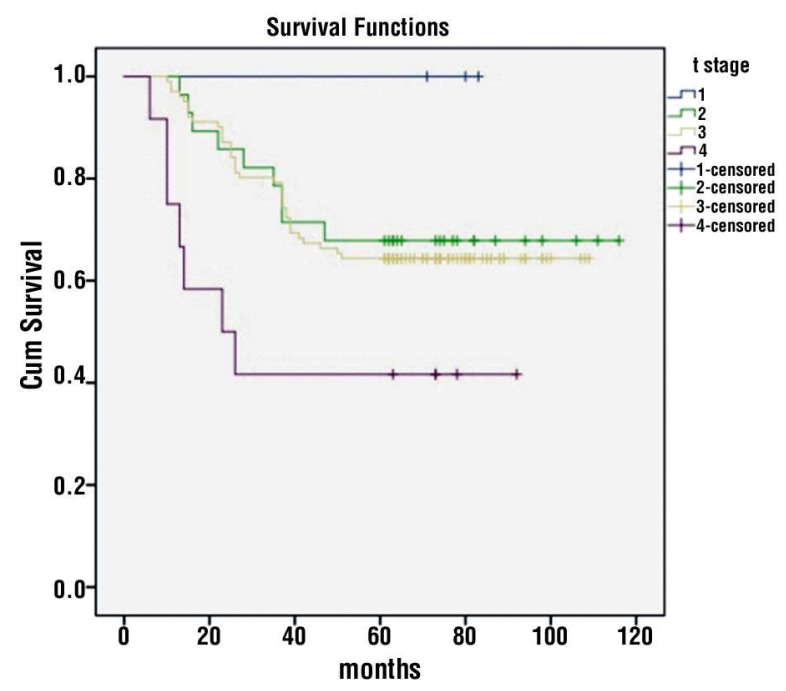

Figure 5. Overall survival based on T stage cant influence on global survival among studied patients $(\mathrm{p}=0.701)$. In patients with tumors located in the upper $1 / 3$ of the rectum the 5-year survival rate was $56.1 \%$, in cases where the tumor was located in the middle $1 / 3$, the survival rate was $67.2 \%$, and in cases, with tumor localized in the lower $1 / 3$, the 5 year survival rate was $73.9 \%$.

\section{Discussion}

The incidence rate of rectal cancer is the eighth globally, while combined with colon cancer, the incidence rate rises to the third most common, $11 \%$ of all cancer diagnoses in the world.

The number of new cases according to Globocan 2018 statistics has $10.2 \%$ of malignant diseases, a high number which follows closely the newly diagnosed lung $(11.6 \%)$ and breast $(11.6 \%)$ cancers $(1,5)$.

The 5-year survival rate in our study is $63.9 \%$, which is slightly lower if is compared with the American Cancer Society data between 2009 and 2015 but also similar to the ICBP SURVMARK-2 project results $(7,8)$.

Colorectal cancer incidence is strongly influenced by gender according to statistics, however, our study did not find significant differences in survival rates based on patient gender, overall mean survival is similar. The higher mortality of colorectal cancer in men appears to be a result of exogenous and/or endogenous factors pre-diagnosis that lead to higher incidence rates $(9,10)$.

Nodal status has been proven to be an important prognostic factor in both overall and five-year survival of rectal cancer patients. In a study by Peng $\mathrm{J}$ et al. lymph node ratio has been identified as a significant influencer of survival rates and high LNR is closely associated with poor survival $(3,11,12)$.

A systematic review and meta-analysis of the lymph node ratio as a prognostic marker in rectal cancer by Karjol U et al. concludes that LNR is a significant predictor of overall and disease-free 5-year survival, and also an independent prognostic factor not influenced 
by neoadjuvant chemoradiotherapy and excised lymph node number (13).

A study by Fulop Zs et al. examining lymph node ratio as an independent prognostic factor in cases with stage II-III rectal cancer, concluded that there was a significant difference between LNR of 0.15 and overall survival, and a LNR $>0.15$ and TNM stage. The number of excised lymph nodes did not correlate with tumor stage, and also did not influence overall survival when 12 or 14 collected lymph nodes were set as the ideal number (14).

In our study lymph node ratio was proven to be a significant predictor of overall survival rate, but also of 5-year survival. However, in several studies have been demonstrated that the LNR is predictive of survival in colorectal cancer is not still used routinely (15).

The number of excised lymph nodes is a highly debated and controversial topic in colorectal surgery. Results from a study by Katia M. Ladeira et al demonstrate that the higher number of excised lymph nodes $(>12)$ correlates with greater survival in colon cancer, but in rectal cancer is no correlation between survival and the number of nodes assessed be larger or smaller/equal to twelve (16).

Our study shows no significant prognostic value of the number of excised nodes in univariate analysis. Also, $\mathrm{T}$ stage proved to be a significant predictor of survival in the patients we studied.

In point of view of the vascular invasion, our results are similar to a retrospective study by Jin-Wei Zhong et al which demonstrates that lymphovascular invasion is an indicator of poor prognosis in patients with colorectal cancer (17).

Based on our experience, young people make up a small minority of rectal cancer, with a more aggressive form of cancer, but the results show that age is an important predictive factor in survival and overall survival is less in the elderly. The strong difference in 5-year survival in $>79$ old patients compared to other age groups highlights that care must be taken in deciding whether radical surgery or palliative care should be offered in considera- tion to allow the best overall survival and quality of life $(18,19,20)$.

Faisal Shahjehan et al. assessed the relation between BMI and colorectal cancer with similar results as found in our study: obese patients had the highest survival and underweight is associated with the highest mortality rate (21). A study published in the Journal of Clinical Oncology with similar results demonstrated that obese patients had improved survival after diagnosis of stage IV colorectal cancer (22).

Our study compared survival rates based on surgical techniques, which resulted in a significant difference in survival, those undergoing low anterior resection, and abdominoperineal resection had a higher survival rate than those undergoing the Hartmann procedure. Probably this is due to the emergency condition and patient's comorbidities. Also, the present study shows that survival is highly influenced in presence of distant metastases in rectal cancer patients.

\section{Conclusion}

The 5-year survival of rectal cancer varies between $61.6 \%$ and $70.9 \%$ and is increasing due to the novel surgical techniques and treatment. Our 5-year survival of $63.9 \%$ is similar and it can be improved by distant disease treatment and earlier diagnosis.

In our study, the survival of rectal cancer patients was significantly influenced by the patient's age, $\mathrm{N}$ stage, $\mathrm{T}$ stage, LNR, type of surgery, vascular invasion, and metastases based on univariate analysis, By multivariate analysis the age, $\mathrm{N}$ stage, LNR vascular invasion and distant metastases proved to be significant prognostic factor in five year survivalAlso, the LNR proved to be an independent prognostic factor for survival.

We consider that it would be useful to implement a probability calculator tool to obtain a more accurate prediction of survival, which can be very useful in daily medical practice.

Examining a larger number of cases from different surgical centers and populations 
would result in having a more precise appreciation of survival predictors, being able to compare survival curves in different standardized data sets.

The follow-up procedure could be improved upon by centralizing patient data from all interactions with healthcare professionals and facilities, in a database accessible only to medical professionals and students, improving not only the quality of information gathered but also on the quantity.

\section{Limitations of the Study}

The present study has several limitations, one of the most important of them is the follow up of the patients, sometimes could be difficult to get information about the actual state of the patient, and also the inclusion of the oncological treatment should be important in survival assessment. Furthermore, with a larger sample size, some of the statistical analysis would have reached significant thresholds. Overall, more extensive further studies are required to elucidate controversies

\section{Conflicts of Interest}

The authors declare no conflicts of interest.

\section{Ethics of Approval}

For performing this study ethical approval was obtained.

\section{References}

1. Bray F, Ferlay J, Soerjomataram I, Siegel RL, Torre LA, Jemal A. Global cancer statistics 2018: GLOBOCAN estimates of incidence and mortality worldwide for 36 cancers in 185 countries. CA Cancer J Clin. 2018;68(6):394-424.

2. Quaresma M, Coleman MP, Rachet B. 40-year trends in an index of survival for all cancers combined and survival adjusted for age and sex for each cancer in England and Wales, 1971-2011: a population-based study Lancet. 2015;385(9974):1206-18. Epub 2014 Dec 3.

3. Yuan Y, Li MD, Hu HG, Dong CX, Chen JQ, Li XF, et al. Prognostic and survival analysis of 837 Chinese colorectal cancer patients. World J Gastroenterol. 2013;19(17):2650-9.
4. Rasouli MA, Moradi G, Roshani D, Nikkhoo B, Ghaderi E, Ghaytasi B. Prognostic factors and survival of colorectal cancer in Kurdistan province, Iran: A population-based study (2009-2014). Medicine (Baltimore). 2017:96(6):e5941.

5. Rawla P, Sunkara T, Barsouk A. Epidemiology of colorectal cancer: incidence, mortality, survival, and risk factors. Prz Gastroenterol. 2019;14(2):89-103.

6. Mehrkhani F, Nasiri S, Donboli K, Meysamie A, Hedayat A. Prognostic factors in survival of colorectal cancer patients after surgery. Colorectal Dis. 2009;11(2):157-61. Epub 2008 May 3.

7. Society AC. "https://www.cancer.org/cancer/colon-rectal-cancer/ detection-diagnosis-staging/survival-rates.html," American Cancer Society, 2020 (Online).

8. Araghi M, Arnold M, Rutherford MJ, Grønlie Guren M, Cabasag CJ, Bardot $A$, et al. Colon and rectal cancer survival in seven highincome countries 2010-2014: variation by age and stage at diagnosis (the ICBP SURVMARK-2 project). Gut. 2020;gutjnl2020-320625. Online ahead of print.

9. Lydrup ML, Höglund P. Gender aspects of survival after surgical treatment for rectal cancer. Colorectal Dis. 2015;17(5):390-6.

10. White A, Ironmonger L, Steele RJC, Ormiston-Smith N, Crawford C, Seims A. A review of sex-related differences in colorectal cancer incidence, screening uptake, routes to diagnosis, cancer stage and survival in the UK. BMC Cancer. 2018;18(1):906.

11. Kim HJ, Choi GS. Clinical Implications of Lymph Node Metastasis in Colorectal Cancer: Current Status and Future Perspectives. Ann Coloproctol. 2019;35(3):109-117.

12. Peng J, Xu Y, Guan Z, Zhu J, Wang M, Cai G, et al. Prognostic significance of the metastatic lymph node ratio in node-positive rectal cancer. 2008;15(11):3118-23.

13. Karjol U, Jonnada P, Chandranath A, Cherukuru S. Lymph Node Ratio as a Prognostic Marker in Rectal Cancer Survival: A Systematic Review and Meta-Analysis. Cureus. 2020;12(5):e8047.

14. Fulop ZZ, Gurzu S, Bara T, Dragus E, Bara T Jr, Voidazan S, et al. Lymph Node Ratio, an Independent Prognostic Factor for Patients With Stage II-III Rectal Carcinoma. Pathol Res Pract. 2019; 215(6):152384

15. Sabbagh C, Mauvais F, Cosse C, Rebibo L, Joly JP, Dromer D, et al. A lymph node ratio of $10 \%$ is predictive of survival in stage III colon cancer: a French regional study. Int Surg. 2014;99(4):344-53.

16. Ladeira KM, Fernandes Martins SF. Prognostic impact of the number of resected lymphnode on survival in Colorectal Cancer. J Coloproctol. 2016;36(3):130-138.

17. Zhong JW, Yang SX, Chen RP, Zhou YH, Ye MS, Miao L, et al. Prognostic Value of Lymphovascular Invasion in Patients with Stage III Colorectal Cancer: A Retrospective Study. Med Sci Monit. 2019;25:6043-6050.

18. Al-Abed Y, Parker M, Arulampalam T, Tutton M. Survival following rectal cancer surgery: does the age matter? Acta Chir Belg. 2019; 119(5):282-288. Epub 2018 Oct 9.

19. Angrand-Escure J, Diao P, Garcia M, Wang G, Guy JB, Espenel S, et al., "Outcome and prognostic factors in 593 non-metastatic rectal cancer patients: a mono-institutional survey. 2018;8(1):10708.

20. van Eeghen EE, Bakker SD, van Bochove A, Loffeld RJ. Impact of age and comorbidity on survival in colorectal cancer. J Gastrointest Oncol. 2015;6(6):605-12.

21. Shahjehan F, Merchea A, Cochuyt JJ, Li Z, Colibaseanu DT, Kasi PM. Body Mass Index and Long-Term Outcomes in Patients With Colorectal Cancer. Front Oncol. 2018;8:620.

22. Tran CG, Hill EE, Jensen B, Stark AC, Flannery M, Berg DJ, Carlos Hou Fai Chan. Survival benefit of obesity in stage IV colorectal cancer: Better tolerability of chemotherapy? J Clin Oncol. 2018;36(15_suppl): e15629-e15629. 